\title{
Correction to: Synthesis of Tinbergen's four questions and the future of sociogenomics
}

\author{
Karen M. Kapheim ${ }^{1}$ (D)
}

Published online: 31 January 2019

(C) Springer-Verlag GmbH Germany, part of Springer Nature 2019

\section{Correction to: Behavioral Ecology and Sociobiology https://doi.org/10.1007/s00265-018-2606-3}

This article is a part of the topical collection "Social complexity: patterns, processes, and evolution". For this reason, though it was originally inadvertently published in 2018 , in Vol. 72, Issue 12, citation ID 186, it has now been reassigned and republished in 2019, in Vol. 73, Issue 1, citation ID 186.

The original article has been corrected.

Publisher's note Springer Nature remains neutral with regard to jurisdictional claims in published maps and institutional affiliations.

The online version of the original article can be found at https://doi.org/ 10.1007/s00265-018-2606-3

Karen M. Kapheim

karen.kapheim@usu.edu

1 Department of Biology, Utah State University, 5305 Old Main Hill, Logan, UT 84341, USA 